\title{
Pemetaan Pasar Dan Strategi Pemasaran Secara Islami Bagi Usaha Mikro Kecil Dan Menengah
}

\author{
Feti Fatimah $^{1}$, Mega Wahyu Rhamadanita ${ }^{2}$, Mohammad Sofianto ${ }^{3}$ \\ Universitas Muhammadiyah Jember ${ }^{1,2,3}$
}

\begin{abstract}
The success of a strategy that has been established largely determined by how much the level of conformity of these strategies with environmental change, competition, as well as the situation of the company. Formulation of the problem in this research is how the mapping market and Islamic marketing strategies in the UMKM business field for Crafts in Jember Regency Balung. The location of this research in Jember Regency Balung. The results of his research is the result of matric Internal External SMEC was at quadrant $V$ which means having Stability/growth strategy to develop future will come. the Islamic Marketing strategies can consist of applying a strategy of maintaining and sustaining, market penetration and product development. SWOT matrix analysis of the SMEC is a Islamic marketing strategy that is in S-O Strategies where this strategy consists of Utilizing Government programmes relating to enterprise development, Developing product quality and Expand market.

Keywords: Mapping, Islam, Market, Strategy, Marketing,
\end{abstract}

\section{Pendahuluan}

Perkembangan dunia usaha saat ini diikuti dengan persaingan yang sangat ketat. Sehingga harus benar-benar jeli dalam menganalisa kesempatan apa saja yang dapat untuk dimanfaatkan dan harus mempersiapkan diri dalam menghadapi ancaman-ancaman yang mungkin akan terjadi dengan menggunakan kekuatankekuatan yang dimilikinya, melakukan segmentasi pasar dan menerapkan strategi pemasaran yang tepat.

Segmentasi pasar merupakan kegiatan membagi suatu pasar menjadi kelompok kelompok pembeli yang berbeda dan membutuhkan produk atau bauran pemasaran yang berbeda. Segementasi pasar juga dapat diartikan sebagai proses pengidentifikasian dan menganalisis para pembeli di pasar produk, menganalisis perbedaan antara pembeli di pasar. Penerapan strategi pemasaran yang tepat dalam menciptakan keunggulan bersaing dan gebrakan-gebrakan baru sangat diperlukan 
guna tercapainya peningkatan efisiensi dan memperbesar pangsa pasar.

Strategi pemasaran menurut Kotler (2007) adalah sebagai berikut: "Strategi pemasaran adalah logika pemasaran, berdasarkan itu unit bisnis diharapkan mencapai sasaran-sasaran pemasaran. Strategi pemasaran terdiri dari pengambilan keputusan tentang biaya pemasaran dari perusahaan, bauran pemasaran dan alokasi pemasaran dalam hubungannya dengan keadaan lingkungan yang diharapkan dan kondisi persaingan".

Penentuan strategi pemasaran yang tepat pada perusahaan berarti perusahaan telah memiliki daya saing didalam pasar. Kemampuan bersaing inilah yang akan menentukan omset penjualan dan profitabilitas yang akan diraih sehingga perusahaan dapat mempertahankan kelangsungan hidupnya.

Keberhasilan suatu strategi yang telah ditetapkan sangat ditentukan oleh seberapa besar tingkat kesesuaian strategi tersebut dengan perubahan lingkungan, persaingan, serta situasi perusahaan. Pada akhirnya perencanaan strategi yang meliputi analisis, perumusan, evaluasi sangat membantu perusahaan dalam menetapkan strategi pemasaran yang tepat. Salah satu contoh strategi pemasaran adalah strategi pemasaran islami. Strategi pemasaran islami adalah strategi pemasaran yang dilakukan berdasarkan nilai-nilai islam yang sesuai dengan konsep ajaran Nabi Muhammad SAW. Nilai inti dari strategi ini adalah harus menghindari hal yang haram baik proses atau hasilnya karena semua hal akan dipertanggung jawabkan dihadapan Allah SWT.

Fundamental perekonomian Indonesia saat ini belum kokoh sehingga mendorong pemerintah untuk terus memberdayakan Usaha Mikro Kecil dan Menengah (UMKM) terutama bidang usaha kerajinan tangan. Sektor ini mampu menyerap tenaga kerja cukup besar dan memberi peluang bagi UMKM untuk berkembang dan bersaing. Namun, UMKM juga menghadapi banyak sekali permasalahan, yaitu terbatasnya modal kerja, Sumber Daya Manusia yang rendah, dan minimnya penguasaan ilmu pengetahuan serta teknologi (Sudaryanto dan Hanim, 2002). Kendala lain yang dihadapi UMKM adalah keterkaitan dengan prospek usaha yang kurang jelas serta perencanaan, visi dan misi yang belum

\section{STIE MANDALA JEMBER}


mantap. Hal ini terjadi karena umumnya UMKM bersifat income gathering yaitu menaikkan pendapatan, dengan ciri-ciri sebagai berikut: merupakan usaha milik keluarga, menggunakan teknologi yang masih relatif sederhana, kurang memiliki akses permodalan (bankable), dan tidak ada pemisahan modal usaha dengan kebutuhan pribadi.

Hasil sensus ekonomi yang dilakukan oleh Badan Pusat Statistik (BPS) bahwa jumlah UMKM di Kabupaten Jember pada tahun 2016 naik 98,96 \% bila dibandingkan dengan hasil sensus tahun 2006. Sedangkan hasil penelitian Fatimah (2018) bahwa identifikasi perilaku konsumen terhadap produk UMKM adalah produk UMKM belum mampu mempengaruhi perilaku konsumen untuk membeli pada UMKM di wilayah jember. UMKM sebagai salah satu bentuk perekonomian rakyat yang memiliki peran besar dalam perekonomian negara, memerlukan model manajemen usaha (Bismala, 2016). Sehingga meski jumlah UMKM bidang usaha kerajinan tangan di Kecamatan Balung Kabupaten Jember berkembang dengan pesat namun masih perlu perbaikan dalam proses pemetaan pasarnya dan penentuan strateginya agar mampu bersaing dengan perusahaan besar. Karena bila dalam pemetaan pasar dan penentuan strateginya melakukan kesalahan maka UMKN tidak mampu fokus dan mengoptimalkan kekuatannya dalam melakukan persaingan didunia usaha.

\section{Perumusan Masalah}

Rumusan masalah dalam penelitian ini adalah bagaimana pemetaan pasar dan strategi pemasaran secara islami bagi UMKM bidang usaha kerajinan tangan di Kecamatan Balung Kabupaten Jember?

Batasan-batasan dalam penelitian ini sebagai berikut.

1. Meneliti masalah strategi pemasaran.

2. UMKM bidang usaha kerajinan tangan di Kecamatan Balung Kabupaten Jember. 


\section{Metode Penelitian}

\section{Sumber data Penelitian}

1. Data Primer. Data primer dalam penelitian ini yaitu jenis usaha, perkembangan dan persaingan UMKM bidang usaha kerajinan tangan di Kecamatan Balung Kabupaten Jember.

2. Data Sekunder. Data sekunder dalam penelitian ini adalah: Gambaran umum obyek penelitian, Visi dan misi UMKM bidang usaha kerajinan tangan di Kecamatan Balung Kabupaten Jember.

\section{Teknik Pengumpulan Data}

Teknik pengumpulan data yang digunakan adalah sebagai berikut (Creswell, 2010 ).

a. Wawancara Mendalam

Mengumpulkan data dengan melakukan wawancara berkaitan dengan visi dan misi serta kondisi UMKM bidang usaha kerajinan tangan di Kecamatan Balung Kabupaten Jember kepada yang memiliki wewenang untuk menjawab wawancara yang dilakukan oleh peneliti.

b. Observasi

Peneliti langsung turun ke lapangan untuk mengamati perilaku dan UMKM bidang usaha kerajinan tangan di Kecamatan Balung Kabupaten Jember.

c. Dokumentasi

Dokumentasi berupa struktur organisasi, serta dokumen-dokumen tentang pendapat dan teori yang berhubungan dengan masalah penelitian

\section{Lokasi dan Waktu Penelitian}

Lokasi penelitian ini di Kecamatan Balung Kabupaten Jember. Waktu yang dibutuhkan dalam penelitian ini adalah 2 bulan.

\section{Hasil Dan Pembahasan}

\section{Gambaran Umum UMKM di Jember}

UMKM di wilayah Jember mengalami kemajuan yang pesat, terutama UMKM di bidang kuliner terutama di wilayah daerah kampus. Hal ini bisa dibuktikan dengan menjamurnya usaha-usaha kuliner di wilayah kampus. UMKM 
untuk bidang kerajinan juga mengalami perkembangan. Banyak pengrajin bermunculan dan sudah memiliki kemampuan untuk mengekspor hasil karyanya. Pusat kerajinan yang terkenal adalah di desa Tutul Kecamatan Balung.

Pemerintahan Jember mendukung perkembangan UMKM di Wilayah Jember dengan cara memberikan pinjaman lunak, mengadakan pelatihan dan pameran untuk tingkat UMKM. Tetapi pemasalahannya para UMKM yang mampu bertahan lebih dari 5 tahun dengan usahanya masih sedikit. Kebanyakan UMKM tumbang sebelum 5 tahun.

Jenis UMKM di wilayah Jember adalah kerajinan, kuliner, bengkel, mebel dan perdagangan. Yang paling berkembang dan menjanjikan adalah usaha kuliner. UMKM kerajinan berkembang pesat di wilayah Jember selatan dan UMKM kuliner berkembang pesat di wilayah kampus.

UMKM bidang usaha kerajinan tangan di Kecamatan Balung Kabupaten Jember adalah manik-manik gelang, tasbih, kalung, alat musik, dan lampu. Yang paling terkenal adalah tasbih yang berasal dari desa Tutul.

\section{Hasil Penelitian}

\section{Analisis Faktor Internal Dan Faktor Eksternal UMKM bidang Usaha Kerajinan Tangan di Kecamatan Balung Kabupaten Jember}

Hasil pengamatan yang telah dilakukan, mulai dari melihat gambaran umum serta kondisi UMKM bidang Usaha Kerajinan Tangan di kecamatan Balung Kabupaten Jember terkini adalah strategi yang telah ditempuh dan kinerja yang telah dicapai dapat diketahui beberapa faktor internal dan eksternal dapat diidentifikasikan sebagai berikut:

\section{a. Faktor Internal}

\section{1) Kekuatan}

a) Produk bervariasi

b) Harga relatif terjangkau

c) Kualitas produk

d) Keunikan produk 


\section{2) Kelemahan}

a) Pelayanan yang masih belum berjalan dengan baik karena waktu penyelesaian pemesanan sering tidak sesuai dengan yang telah disepakati..

b) Promosi yang di lakukan belum dilakukan secara terstruktur.

c) Kekurangan modal

\section{b. Faktor Eksternal}

\section{1) Peluang}

a) Pemerintah memberikan dukungan bagi kemajuan UMKM.

b) Pasar masih luas

2) Ancaman

a) Munculnya kompetitor baru

b) Permainan harga dari pesaing yang membuat UMKM harus bertahan dengan harga yang relatif murah, serta mengikuti harga pasar

c) Promosi dari pihak lain lebih menarik terutama yang dilakukan perusahaan yang memiliki modal besar. 


\section{Matriks SWOT \\ Matriks Internal Factor Evaluation (IFE)}

Matriks Internal Factor Evaluation (IFE)

\begin{tabular}{|c|c|c|c|c|}
\hline $\begin{array}{l}\text { Faktor-faktor } \\
\text { Internal }\end{array}$ & Bobot & Rating & $\begin{array}{l}\text { Bobot X } \\
\text { Rating }\end{array}$ & Keterangan \\
\hline
\end{tabular}

\begin{tabular}{ccccc}
\hline $\begin{array}{l}\text { Kekuatan } \\
\text { a) Produk } \\
\text { bervariasi }\end{array}$ & 0,15 & 3 & 0,45 & $\begin{array}{l}\text { Mempengaruhi } \\
\text { minat konsumen }\end{array}$ \\
$\begin{array}{l}\text { b) Harga relatif } \\
\text { terjangkau }\end{array}$ & 0,10 & 4 & 0,4 & $\begin{array}{l}\text { Mempengaruhi } \\
\text { minat konsumen }\end{array}$ \\
c) Kualitas produk & 0,15 & 4 & 0,6 & $\begin{array}{l}\text { Mempengaruhi } \\
\text { minat konsumen }\end{array}$ \\
d) Keunikan & 0,15 & 4 & 0,6 & $\begin{array}{l}\text { Tidak ada alasan } \\
\text { untuk memilih }\end{array}$ \\
produk & & & &
\end{tabular}

Sub Total $\quad 0,5 \quad 2,05$

Kelemahan

$\begin{array}{llccl}\text { a) Pelayanan } & 0,15 & 2 & 0,3 & \begin{array}{l}\text { Hambatan } \\ \text { Pembelian }\end{array} \\ \text { b) Promosi } \\ \begin{array}{l}\text { yang belum } \\ \text { terstruktur }\end{array} & 0,1 & 1 & 0,1 & \begin{array}{l}\text { Hambatan } \\ \text { pemasaran }\end{array} \\ \text { c) Kekurangan } & 0,1 & 2 & 0,2 & \text { Hambatan } \\ \text { modal } & & & & \text { Pemasaran }\end{array}$

$\begin{array}{ccc}\text { Sub total } & \mathbf{0 , 3 5} & \mathbf{0 , 6} \\ \text { Total } & 0,85 & \mathbf{2 , 6 5}\end{array}$

Sumber : data primer diolah (2019)

1. Kekuatan $($ Strenghts $/ S) \quad \mathbf{2}, \mathbf{2 5}$

2. Kelemahan (Weaknesses $/ W) \quad=\mathbf{0 , 5}$

0,15 Merupakan interprestasi jawaban informan terkait faktor strategi penting dalam skala pembobotan. 
0,10 Merupakan interprestasi jawaban informan terkait faktor strategi kurang penting dalam skala pembobotan

Dari pemetaan SWOT tabel 1 bobot ditentukan berdasar pada isian kuisioner (Umar,2005), dimana acuan dari bobot tersebut adalah Bobot ditentukan sebagai berikut:

\section{Bobot Pada Isian Kuisioner}

\begin{tabular}{|c|c|}
\hline Bobot & Keterangan \\
\hline 0,15 & Penting \\
\hline 0,10 & Kurang Penting \\
\hline 0,5 & Rata-rata \\
\hline 0,0 & Tidak Penting \\
\hline
\end{tabular}

Matriks Eksternal Factor Evaluation (EFE)

Tabel 2. Matriks Eksternal Factor Evaluation (EFE)

\begin{tabular}{|c|c|c|c|c|}
\hline Faktor-Faktor Eksternal & Bobot & Rating & $\begin{array}{l}\text { Bobot X } \\
\text { Rating }\end{array}$ & Keterangan \\
\hline \multicolumn{5}{|l|}{ Peluang } \\
\hline $\begin{array}{l}\text { a) Pemerintah } \\
\text { memberikan dukungan } \\
\text { bagi kemajuan UMKM }\end{array}$ & 0,15 & 4 & 0,6 & $\begin{array}{l}\text { Mempengaruhi } \\
\text { Perkembangan } \\
\text { Usaha }\end{array}$ \\
\hline b) Pasar masih luas & 0,15 & 3 & 0,45 & Peluang besar \\
\hline Sub Total & $\mathbf{0 , 3}$ & & 1,05 & \\
\hline \multicolumn{5}{|l|}{ Ancaman } \\
\hline $\begin{array}{l}\text { a) Munculnya } \\
\text { kompetitor baru }\end{array}$ & 0,15 & 4 & 0,6 & $\begin{array}{l}\text { Persaingan } \\
\text { sehat }\end{array}$ \\
\hline $\begin{array}{l}\text { b) Permainan harga } \\
\text { dari pesaing }\end{array}$ & 0,15 & 3 & 0,45 & $\begin{array}{l}\text { Menarik } \\
\text { konsumen }\end{array}$ \\
\hline $\begin{array}{l}\text { c) Promosi dari pihak lain } \\
\text { dapat menarik } \\
\text { konsumen }\end{array}$ & 0,15 & 3 & 0,45 & $\begin{array}{l}\text { Menarik } \\
\text { konsumen }\end{array}$ \\
\hline Sub total & 0,35 & & 1,5 & \\
\hline Total & 0.65 & & 2,55 & \\
\hline
\end{tabular}




\section{Matriks IE ( Internal Eksternal )}

Tabel IFE 6.2 dan Tabel EFE 6.4 diketahui bahwa skor untuk faktor strategis internal sebesar 2,65 berarti bahwa UMKM memiliki kekuatan dan kelemahan ratarata yang dimiliki oleh UMKM dapat dimanfaatkan meminimalkan kelemahan sedang skor total faktor eksternal sebesar 2,55 memberikan arti bahwa pada UMKM mempunyai kekuatan serta peluang untuk tumbuh dan berkembang di masa yang akan mendatang dengan melakukan antisipasi terhadap ancaman seiring dengan pertumbuhan dan perkembangan yang terjadi. Untuk mengetahui gambaran strategi perusahaan maka berdasarkan formulasi IFE dan EFE selanjutnya di perhitungkan dalam matrik internal eksternal IE matrik.

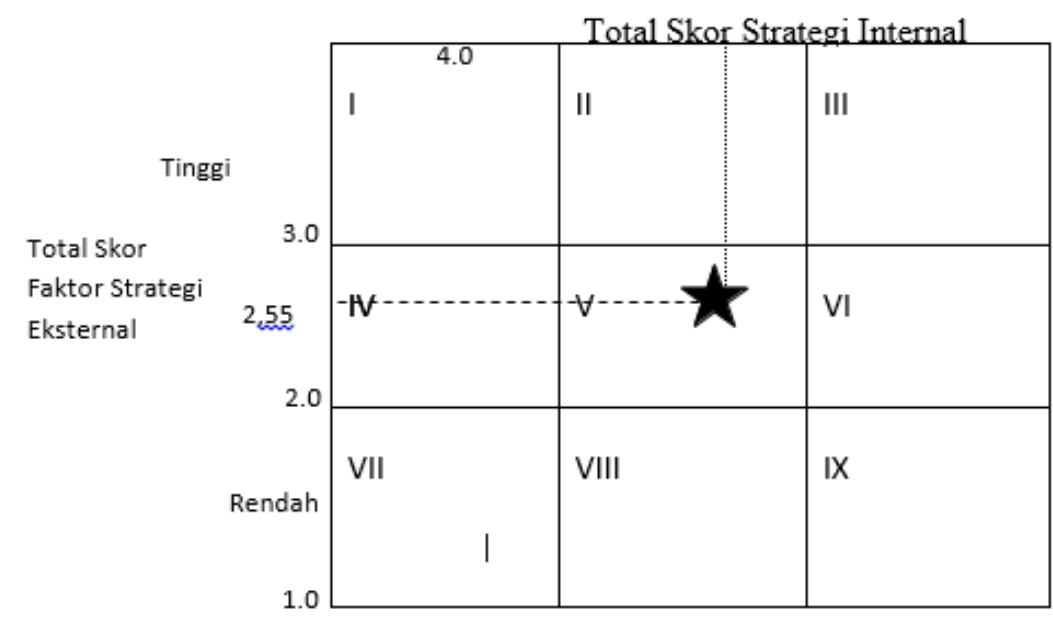

Gambar 6.1 Matrik IE

Berdasarkan formulasi IE matrik yang di dapatkan pada posisi UMKM yaitu berada di pada Kuadrat V yang bertanda astrix $(2,65 ; 2,55)$ dalam kuadran V ini berarti UMKM seharusnya menerapkan strategi Stabilitas/Pertumbuhan. Strategi stabilitas/Pertumbuhan merupakan strategi yang dapat di terapkan perusahaan apabila :

a. UMKM mengembangkan kualitas produk

b. UMKM mengembangkan keunikan produk

c. Menetapkan harga yang bersaing

Penerapan strategi ini agar UMKM dapat tetap bertahan dan berkembang. 


\section{Posisi Matriks SWOT UMKM}

Tabel 6.15 Matriks SWOT UMKM

\begin{tabular}{|c|c|c|}
\hline$\underset{\mathrm{S}}{\text { IFA }}$ & $\begin{array}{l}\text { Kekuatan / Strengths } \\
\text { (S) } \\
\text { 1. Produk bervariasi } \\
\text { 2. Harga relatif } \\
\text { terjangkau } \\
\text { 3. Kualitas produk } \\
\text { 4. Keunikan produk }\end{array}$ & $\begin{array}{l}\text { Kelemahan / } \\
\text { Weaknesess }(\boldsymbol{W}) \\
\text { 1. Pelayanan yang masih } \\
\text { belum berjalan } \\
\text { dengan baik karena } \\
\text { waktu penyelesaian } \\
\text { pemesanan sering } \\
\text { tidak sesuai dengan } \\
\text { yang telah disepakati.. } \\
\text { 2. Promosi yang di } \\
\text { lakukan belum } \\
\text { dilakwkan secara }\end{array}$ \\
\hline $\begin{array}{l}\text { Peluang/ } \\
\text { Opportunities }(\mathbf{O}) \\
\text { 1. Pemerintah } \\
\text { memberikan } \\
\text { dukungan bagi } \\
\text { kemajuan UMKM. } \\
\text { 2. Pasar masih luas }\end{array}$ & $\begin{array}{l}\text { Strategi SO } \\
\text { a. Memanfaatkan } \\
\text { program-program } \\
\text { pemerintah yang } \\
\text { berkaitan dengan } \\
\text { pengembangan } \\
\text { usaha } \\
\text { b. Mengembangkan } \\
\text { kualitas produk }\end{array}$ & $\begin{array}{l}\text { Strategi WO } \\
\text { a. Menambah SDM } \\
\text { untuk meningkatkan } \\
\text { kualitas layanan } \\
\text { b. Meningkatkan } \\
\text { jaringan promosi } \\
\text { yang lebih luas dan } \\
\text { terstruktur. } \\
\text { c. Melakukan inovasi }\end{array}$ \\
\hline $\begin{array}{l}\text { Ancaman / Threats } \\
\text { (T) } \\
\text { 1. Munculnya } \\
\text { kompetitor baru } \\
\text { 2. Permainan harga } \\
\text { dari pesaing yang } \\
\text { membuat UMKM } \\
\text { harus bertahan } \\
\text { dengan harga yang } \\
\text { relatif murah, serta } \\
\text { mengikuti harga } \\
\text { pasar } \\
\text { 3. Promosi dari pihak }\end{array}$ & $\begin{array}{l}\text { Strategi S-T } \\
\text { a. Mempertahankan } \\
\text { Kualitas dan harga } \\
\text { b. Mengembangkan } \\
\text { strategi pemasaran } \\
\text { dengan terus } \\
\text { meningkatkan } \\
\text { promosi }\end{array}$ & $\begin{array}{l}\text { Strategi W-T } \\
\text { a. Mengembangkan } \\
\text { kulitas pelayanan } \\
\text { yang baik } \\
\text { b. Mengembangkan } \\
\text { promosi baik dan } \\
\text { terstruktur di media } \\
\text { massa } \\
\text { b. Menetapkan harga } \\
\text { yang bersaing }\end{array}$ \\
\hline
\end{tabular}

Sumber : Data primer diolah (2019) 
Berdasarkan Matriks SWOT diatas dapat dijelaskan bahwa terdapat empat set pilihan strategi yang dapat diterapkan oleh UMKM diantaranya :

\section{Strategi S-O}

a. Memanfaatkan program-program pemerintah yang berkaitan dengan pengembangan usaha

b. Mengembangkann kualitas produk

c. Memperluas pasar

\section{Strategi W - O}

a. Menambah SDM untuk meningkatkan kualitas layanan

b. Meningkatkan jaringan promosi yang lebih luas dan terstruktur.

c. Melakukan inovasi

Kualitas pelayanan yang masih belum memenuhi harapan konsumen adalah pelayanan yang masih belum berjalan dengan baik karena waktu penyelesaian pemesanan sering tidak sesuai dengan yang telah disepakati, hal ini dikarenakan kurangnya jumlah karyawan. UMKM untuk meningkatkan pelayanan harus menambah jumlah karyawan. Apabila UMKM belum mampu menambah karyawan, maka UMKM tersebut harus menambah kualitas para karyawannya agar dapat bekerja lebih cepat dengan kualitas yang sesuai dengan standar.

Kualitas pelayanan secara islami adalah upaya pemenuhan kebutuhan dan keinginan konsumen serta ketepatan penyampaiannya dalam mengimbangi harapan konsumen dengan berpegang teguh pada hukum islam. Strategi W-O meningkatkan jaringan promosi secara islami untuk meminimalkan kelemahan perusahaan dengan memanfaatkan peluang yang dimiliki perusahaan, mengenai peerkembangan promosi diantaranya meningkatkan bauran promosi agar produk UMKM dapat lebih dikenal oleh masyarakat terkhusus dikota jember, diantaranya :

a. Membuat brosur iklan yang memuat informasi produk UMKM.

Memasang spanduk iklan pada lokasi yang cukup strategis yang dapat dilihat dari berbagai arah. 
b. Lebih aktif dalam membagikan informasi pada jejaring sosial seperti, Facebook, Instagram, Twitter, dan lain lain.

Kemudian strategi selanjutnya yang perlu diterapkan oleh UMKM yaitu Melakukan inovasi produk agar produk dapat selalu diterima oleh konsumen dan juga dapat bersaing.

\section{Strategi S-T}

a. Mempertahankan kualitas dan harga

b. Mengembangkan strategi pemasaran dengan terus meningkatkan promosi

Kotler dan Amstrong (2012) harga adalah sejumlah uang yang dibebankan akan suatu produk, atau jumlah dari nilai yang ditukar konsumen atas manfaatmanfaat kerena memiliki atau menggunkan produk tersebut. Harga memiliki dua peran utama dalam proses pengambilan keputusan para pembeli yaitu :

a. Peranan alokasi dari harga

b. Peranan informasi dari harga

Strategi Promosi yaitu meningkatkan jaringan yang dilakukan guna meminimalkan kelemahan perusahaan dengan memanfaatkan peluang yang dimiliki perusahaan, mengenai perkembangan promosi diantaranya meningkatkan bauran promosi agar produk UMKM dapat lebih dikenal oleh masyarakat serta melakukan promosi secara terstruktur.

\section{Strategi W-T}

a. Mengembangkan kualitas pelayanan yang baik

b. Mengembangkan promosi baik dan terstruktur di media massa

c. Menetapkan harga yang bersaing

Kualitas pelayanan secara islami akan berdampak langsung pada citra perusahaan. Kualitas pelayanan secara islami juga membuat UMKM memiliki nilai positif di mata konsumen, sehingga konsumen tersebut akan memberikan feedback yang baik, serta bukan tidak mungkin akan menjadi pelanggan tetap atau repeat buyer. Maka dari itu, sangat penting untuk mempertimbangkan aspek kepuasan pelanggan terkait kualitas pelayanan 
yang diberikan. Jenis-jenis pelayanan yang dapat diberikan misalnya berupa kemudahan, kecepatan, kemampuan, dan keramahtamahan yang ditunjukkan melalui sikap dan tindakan langsung kepada konsumen.

Menurut Kotler dan Amstrong (2012) Bauran pemasaran adalah perangkat pemasaran yang baik yang meliputi, produk, penentuan harga, promosi, distribusi, digabungkan untuk menghasilkan respon yang diinginkan pasar sasaran. Dari pengertian diatas terlihat bahwa promosi menjadi bagian penting untuk dapat menghasilkan respon yang diinginkan pasar. "Promosi (promotion) merupakan kegiatan yang dilakukan oleh perusahaan untuk mengkomunikasikan manfaat dari produk atau jasa dan meyakinkan konsumen sasaran tentang produk yang mereka hasilkan." Pada dasarnya, komunikasi dapat menginformsikan dan membuat konsumen potensial menyadari atas keberadaan produk yang ditawarkan. Oleh karena komunikasi pemasaran merupakan usaha untuk menyampaikan pesan kepada publik terutama konsumen sasaran mengenai keberadaan produk dipasar.

Selanjutnya yaitu UMKM harus menetapkan harga yang dapat bersaing untuk mempertahankan konsumennya Penetapan harga harus diarahkan demi tercapainya tujuan. Sasaran penetapan harga dibagi menjadi tiga yaitu : (Stanton, 2012)

1. Berorientasi pada laba untuk:

a. Mencapai target laba investasi atau laba penjualan perusahaan.

b. Memaksimalkan laba

2. Berorientasi pada penjualan untuk:
a. Meningkatkan penjualan.
b. Mempertahankan atau meningkatkan pangsa pasar.

3. Berorientasi pada status quo untuk:
a. Menstabilkan harga
b. Menangkal persaingan 
Kebijaksanaan harga dibuat dengan tiga pemikiran, yaitu :

1. Harta ditetapkan diatas pesaing.

2. Harta ditetapkan dibawah pesaing

3. Mengikuti harga saingan

Dari empat kemungkinan alternatif strategi yang diperoleh diatas, strategi yang paling tepat digunakan oleh UMKM guna tetap meningkatkan penjualan yaitu perumusan strategi yang efektif akhirnya diperoleh adalah strategi SO yaitu strategi dengan menggunakan Strength untuk memanfaatkan Opportunies yang dimiliki perusahaan yaitu

a. Memanfaatkan program-program pemerintah yang berkaitan dengan pengembangan usaha

b. Mengembangkann kualitas produk

Memperluas pasar Berdasarakan hasil analisis SWOT yang dilakukan bahwa UMKM memiliki kekuatan yang dapat dipakai pada strategi tertentu serta memanfaatkan peluang yang tepat serta secara bersamaan meminimalkan atau menghindari kelemahan dan ancaman yang ada. Posisi ini sangat menguntungkan perusahaan dengan memperbaiki kondisi diatas rata-rata kemampuan sehinggah UMKM dapat mengendalikan para pesaing yang ada maupun pesaing yang memiliki kekuatan

\section{Pembahasan}

Dari Hasil Matrik Internal Eksternal di atas UMKM berada pada kuadran V yang bertanda asterix $(2,65 ; 2,55)$ yang artinya mempunyai strategi Stabilitas/pertumbuhan untuk berkembang di masa yang akan mendatang strategi yang dapat di terapkan terdiri dari strategi :

\section{Menjaga Dan Mempertahankan}

Strategi ini dapat digunakan jika UMKM menjaga kekuatan yang dimiliki UMKM serta menjaga kualitas produk

\section{Penetrasi pasar}

Penetrasi pasar dilakukan dengan menggunakan strategi pemilihan pasar dengan menggunakan marketing mix. Meningkatkan pangsa pasar yang sudah

\section{STIE MANDALA JEMBER}


lama untuk produk tertentu melalui usaha pemasaran secara islami yakni fokus strategi ini yaitu UMKM harus meningkatkan pemasaran secara terstruktur untuk meningkatkan minat konsumen yaitu dengan melakukan promosi secara islami untuk menarik konsumen baik dari sosial media maupun iklan media massa. Dalam melakukan promosi ini menggunakan prinsip islam yaitu promosi sesuai dengan kenyataan.

Strategi selanjutnya untuk penetrasi pasar yaitu UMKM harus merancang strategi produk mulai model, kemasan, pelayanan dan lain-lain karena ini menjadi salah satu kunci sukses jika kesan tidak menarik maka konsumen akan merasa tidak puas oleh karena itu strategi ini juga penting untuk di digunakan.

Lalu memperhatikan Positioning produk secara konsisten Hal ini penting untuk menanggapi kondisi pasar seperti perang harga. Oleh karena itu UMKM harus mempunyai strategi untuk menetapkan harga yang murah agar konsumen lebih tertarik.

\section{Pengembangan Produk}

Strategi Pengembangan produk secara islami bagi UMKM adalah menambah variasi model dan kualitas produk yang sesuai dengan hukum islam sehingga konsumen merasa puas dengan adanya pengembangan produk yang ada.

Setelah di analisis hasil matrik SWOT UMKM ini mempunyai strategi pertama yaitu Strategi S-O adalah strategi yang memanfaatkan kekuatan perusahaan untuk meraih peluang yang ada pada lingkungan luar, guna memperoleh keuntungan bagi perusahaan beberapa strategi secara islami yang dapat di lakukan UMKM yaitu harus Menjaga Kualitas Produk agar konsumen merasa puas karena produk yang mereka beli berkualitas. Menjaga kualitas produk sangat penting untuk meyakinkan konsumen bahwa produk yang terbaik menurut kebutuhan konsumen. Bahkan untuk lebih meyakinkan UMKM harus memberi jaminan ganti rugi bila produknya tidak berkualitas. Strategi selanjutnya yaitu strategi Penetapan harga harus diarahkan demi tercapainya tujuan. Penetapan harga bertujuan untuk mencari laba agar 
perusahaan dapat berjalan namun dalam kondisi persaingan yang semakin ketat tujuan mencari laba maksimal dalam praktisnya akan sulit dicapai. Oleh karena itu, manajemen memerlukan tujuan-tujuan. Menurut Kotler dan Keller (2016), terdapat beberapa tujuan penetapan harga, antara lain Kemampuan Bertahan (Survival), Laba Maksimum Saat ini (Maximum Current Profit), Pangsa Pasar Maksimum (Maximum Market Share). lokasi usaha adalah tempat perusahaan beroperasi atau tempat perusahaan melakukan kegiatan untuk menghasilkan barang dan jasa yang mementingkan segi ekonomi. Lokasi usaha hal utama yang perlu dipertimbangkan, dengan lokasi yang strategis menentukan keberhasilan sebuah perusahaan.

\section{Pengembangan strategi pemasaran pada UMKM}

Hasil alternatif strategi pemasaran secara islami untuk UMKM yang terolah peneliti dan pihak manajemen berdiskusi untuk menentukan strategi pemasaran secara islami pada UMKM yang benar-benar sesuai dengan situasi dan kondisi serta tujuan hasil diskusi dari peneliti dan pihak UMKM antara lain Pengembangan strategi pemasaran yang belum di lakukan UMKM sebelumnya dan akan di kembangkan UMKM untuk masa yang akan datang yaitu mengembangkan kualitas produk yang ada serta menambah variasi model dengan menggunakan prinsip-prinsip islam.

\section{Kesimpulan}

Berdasarkan hasil penelitian dapat disimpulkan

1. Hasil Matrik Internal Eksternal adalah UMKM berada pada kuadran V yang bertanda asterix $(2,65 ; 2,55)$ yang artinya mempunyai strategi Stabilitas/pertumbuhan untuk berkembang di masa yang akan mendatang. Strategi pemasara secara islami yang dapat di terapkan terdiri dari strategi Menjaga dan Mempertahankan, Penetrasi Pasar dan Pengembangan Produk.

2. Analisis matrik SWOT UMKM mempunyai strategi pemasaran secara islami pertama yaitu Strategi S-O dimana strategi ini yang memanfaatkan kekuatan perusahaan untuk meraih peluang yang ada pada lingkungan luar, guna memperoleh keuntungan bagi perusahaan beberapa strategi yang di lakukan 
UMKM yaitu harus Menjaga Kualitas Produk, Menetapkan harga yang dapat bersaing serta memanfaatkan lokasi yang strategis.

3. Hasil alternatif strategi perusahaan yang terolah peneliti dan pihak manajemen berdiskusi untuk menentukan strategi pengembangan pemasaran pada UMKM yang benar-benar sesuai dengan situasi dan kondisi serta tujuan hasil diskusi dari peneliti dan pihak UMKM antara lain Pengembangan strategi pemasaran secara islami yang belum di lakukan UMKM sebelumnya dan akan di kembangkan UMKM untuk masa yang akan datang yaitu mengembangkan kualitas produk yang ada serta akan menambah variasi model dengan berdasarkan prinsip-prinsip islam.

Berdasarkan hasil penelitian yang sudah dilakukan, maka saran yang mungkin dapat bermanfaat sebagai bahan pertimbangan dan masukan bagi UMKM antara lain: 1. Harus melaksanakan atau menjalankan strategi mempertahankan produk yang ada dengan cara meningkatkan variasi model dan kualitas.; 2. UMKM dalam perkembangan harus menerapan strategi S-O yaitu Mengambangkan kualitas produk seperti inovasi produk, menetapkan harga yang bersaing.; 3. Bagi Peneliti berikutnya, agar mengetahui perkembangan strategi Pemasaran secara islami pada UMKM khususnya pada kerajinan tangan, akan lebih baik jika nantinya menambah objek penelitian lebih dari satu jenis usaha dan wilayah yang lebih luas untuk mendapat hasil yang lebih lengkap dan terinci.

\section{DAFTAR PUSTAKA}

Amirullah. 2015. Manajemen Strategi. Edisi pertama. Mitra Wacana Media. Jakarta.

Assauri, Sofjan. 2013. Manajemen Pemasaran. Rajawali PersPhilip. Jakarta.

Basu, Swastha DH., Irawan. 2008. Manajemen Pemasaran Modern, Edisi Kedua, Cetakan Ke-tigabelas. Liberty Offset. Yogyakarta.

Bismala, Lila. 2016. Model Manajemen Usaha Mikro Kecil dan Menengah (UMKM) untuk Meningkatkan Efektivitas Usaha Kecil Menengah. Jurnal Entrepreneur dan Entrepreneurship, Volume 5, Nomor 1, Maret 2016. Medan. 
Creswell, J.W. 2010. Research design: pendekatan kualitatif, kuantitatif, dan mixed. PT Pustaka Pelajar. Yogjakarta.

David, Fred R, 2011. Strategic Management, Buku 1. Edisi 12 Jakarta.

Fatimah, F. 2018. Strategi Kreatif UMKM Kerajinan Tangan Di Era Digital Pada Wilayah Kabupaten Jember Jurnal Unmuh ember Prosiding Ekonomi Kreatif di Era Digital Vol 1, No 1

Freddy. 2014. Analisis SWOT: Teknik Membedah Kasus Bisnis. Gramedia Pustaka Utama. Jakarta.

Husein, Umar. 2005. Metode Penelitian. Salemba Empat. Jakarta.

John A. dan Robinson Richard B.Jr. 2008. Manajemen Strategis 10. Salemba Empat. Jakarta.

Kotler dan Amstrong. 2012. Prinsip-prinsip pemasaran, Edisi kedua belas, Jilid 1. Erlangga Jakarta.

Kotler, Philip. 2007. Manajemen Pemasaran, Jilid I dan II. PT.Indeks. Jakarta. Lupiyoadi. 2001. Manajemen Pemasaran Jasa Teori dan Praktek. Salemba Empat, Jakarta.

Moleong, L.J. 2011. Metodologi Penelitian Kualitatif. Edisi Revisi. PT Remaja Rosdakarya. Bandung.

Mondy, R. Wayne. 2008. Manajemen Sumber Daya Manusia. Jilid 1 Edisi Sepuluh. Erlangga. Jakarta.

Pearce II, John A. dan Robinson Richard B.Jr. (2008). Manajemen Strategis 10. Salemba Empat : Jakarta

Sudaryanto dan Hanim, Anifatul. 2002. Evaluasi kesiapan UKM Menyongsong Pasar Bebas Asean (AFTA) : Analisis Perspektif dan Tinjauan Teoritis. Jurnal Ekonomi Akuntansi dan Manajemen, Vol 1 No 2.Desember 2002.

Stanton, William J. 2012. Prinsip Pemasaran, Alih Bahasa: Yohaness Lamarto: Penerbit Erlangga. Jakarta

Umar, Husein. 2005. Metode Penelitian. Salemba Empat. Jakarta.

http://id.m.wikipedia.org 27/01/19 jam 13.39 